\title{
Landscape and Astronomy in Megalithic Portugal: the Carregal do Sal Nucleus and Star Mountain Range
}

\author{
Fabio Silva*
}

Central Portugal, delimited by the Douro river to the north and the Mondego to the south, is the second densest region of megalithic monuments in the country. The Neolithic archaeological record indicates seasonal transhumance between higher pastures in the summer and lower grounds in the winter. The monuments are found in lower ground and it has been suggested that they were built during the winter occupation of their surroundings. The astronomical orientation of their entrances lends further support to this hypothesis. A recent survey of the orientation of the chambers and corridors of these dolmens, conducted by the author, found good agreement with prior surveys, but also demonstrated that other interpretations are possible. This paper presents an update on the survey, including extra sites surveyed in the spring of 2011, as well as the GIS confirmation of all horizon altitudes that couldn't be empirically measured. The megalithic nucleus of Carregal do Sal, on the Mondego valley, is then looked at in more detail. It is found that there is a preference for the orientation of dolmens towards Star Mountain Range inline with the topographic arguments of landscape archaeology. In addition, it was found that the topography also marks the rise of particular red stars, Betelgeuse and Aldebaran, during the period of megalithic building, at the onset of spring marking the transition from low ground to the high pastures. This hypothesis finds further support from toponymic folktales that explain the origin of the name of the mountain range.

The Mondego platform of central Portugal is bordered by the Central Massif to the southeast, the Marginal Massif to the west and northwest, and the Douro basin to the north (see Fig. 1). The area covers most of the drainage basins of the upper Mondego, the Vouga and part of the Douro rivers. The Central Massif, especially Star Mountain Range, offers good pastures during the spring and summer seasons and has evidence of human

\footnotetext{
* UCL Institute of Archaeology

31-34 Gordon Square, London WC1H OPY

United Kingdom

fabio.silva@ucl.ac.uk
}

usage since the fifth millennium BC (Cruz 2001: 297). Shortly after this early Neolithic occupation, megalithic dolmens and tumuli began to punctuate the surrounding landscape and are especially concentrated around the most important rivers of the region.

Passage graves, dolmens and other megaliths throughout the Atlantic façade of Europe are located and oriented according to the landscape (Tilley 1994), but also towards particular astronomical events (Ruggles 1999). In the 1980s Michael Hoskin surveyed dolmens in this region of Portugal and concluded them to be loosely oriented towards sunrise/climb at the moment they were 
built (Hoskin et al. 1998; Hoskin 2001). The current and on-going research project was designed to expand on the measurements of Hoskin and reassess the data using up-todate methodological tools (Silva 2010).

\section{The Early Neolithic of the Mondego Platform}

Evidence for the occupation of the Mondego platform prior to the Neolithic is scarce. To the northeast, in the Coa valley, famous for its Upper Palaeolithic open-air rock art sites, a few microliths, possibly Mesolithic, were discovered underneath levels with ceramics and polished stone (Rodrigues 2000). These levels have been radiocarbon dated to about 6400-6100 BC ${ }^{1}$. In Oliveira do Bairro, in the Vouga basin, and close to where the coastline would have been at the onset of the Holocene, microblade finds have been attributed to the Mesolithic, at about 6500-5500 BC (Silva 2000). Based on these finds Cruz considers that the Mondego platform was not devoid of Mesolithic occupation but that most settlements in the Vouga and Mondego basins would most likely be now submerged or destroyed by the rising water levels (Cruz 2001: 296).

Zilhao proposed a Maritime Pioneer Colonisation model for the arrival of farming, and the Neolithic, in Portugal (2001, 2003). In his model, agricultural communities were formed by pioneer colonists that leap-frogged along the coast of the Mediterranean. This would have occurred at least between central Italy and Portugal, and is supported by similarities in ornaments and pottery decoration between the two extreme regions, the littoral placement of settlements, as well as radiocarbon dating indicating a swift movement (Zilhao 2001: 14184). Mesolithic communities thrived for about 500 years after the first Neolithic societies appear in the archaeological record, as the latter mostly occupied territories previously unoccupied by Mesolithic hunter-gatherers.

Discoveries of the past twenty years, especially of Neolithic settlements in the Mondego basin, have allowed a picture of local life during the fifth millennium $B C$, the

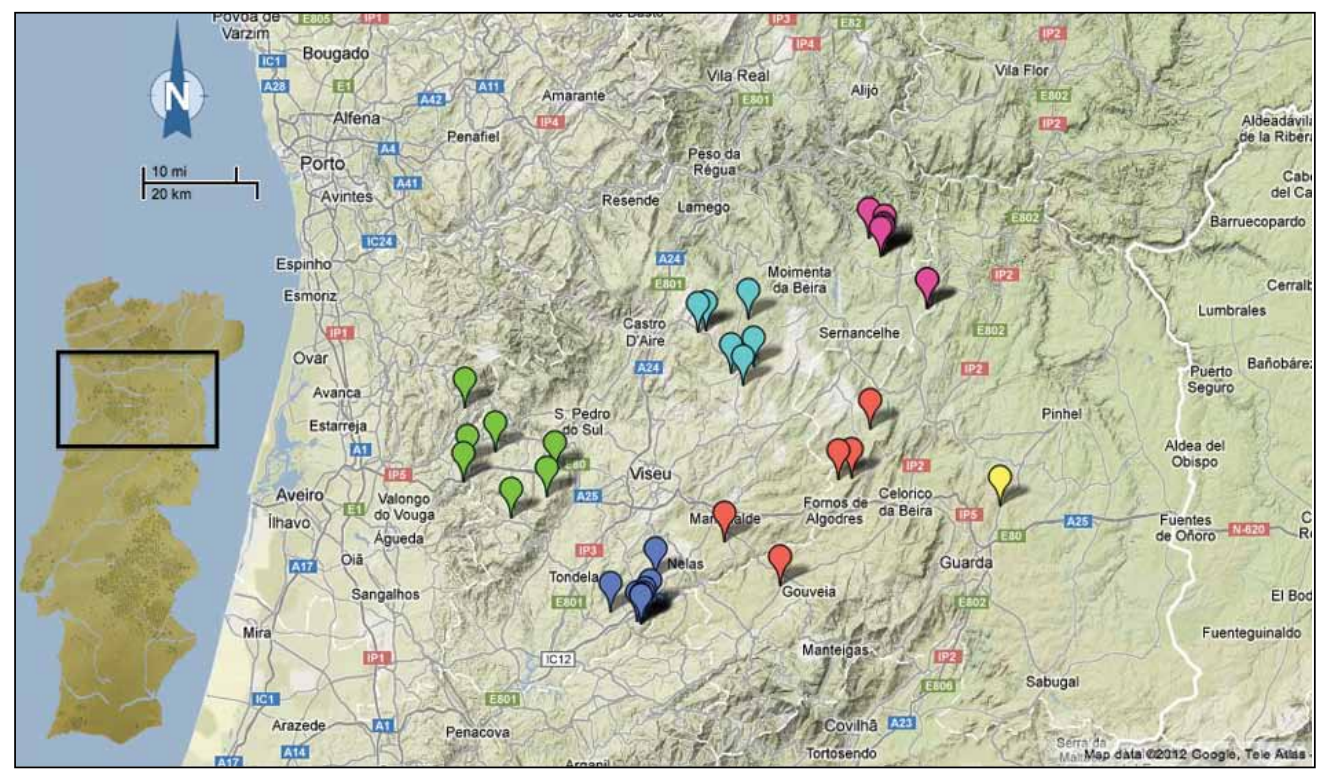

Fig. 1: Map of Portugal, with distribution of megalithic monuments and the region under study (inset). The enlarged map of the Mondego platform shows the location of all surveyed dolmens, coloured by river basin: green for Vouga, dark blue and red for Mondego, light blue for Paiva, pink for Torto and yellow for Coa. 


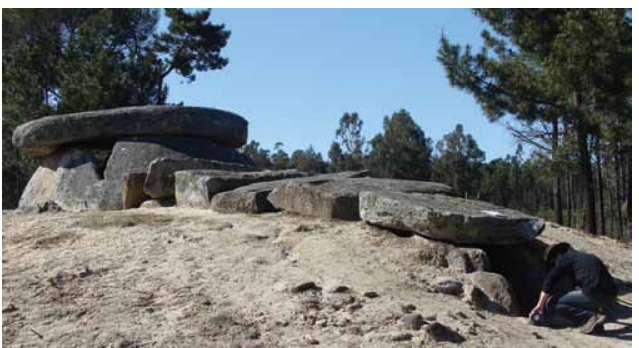

Fig. 2: Dolmen da Orca with extant coverstones and cairn.

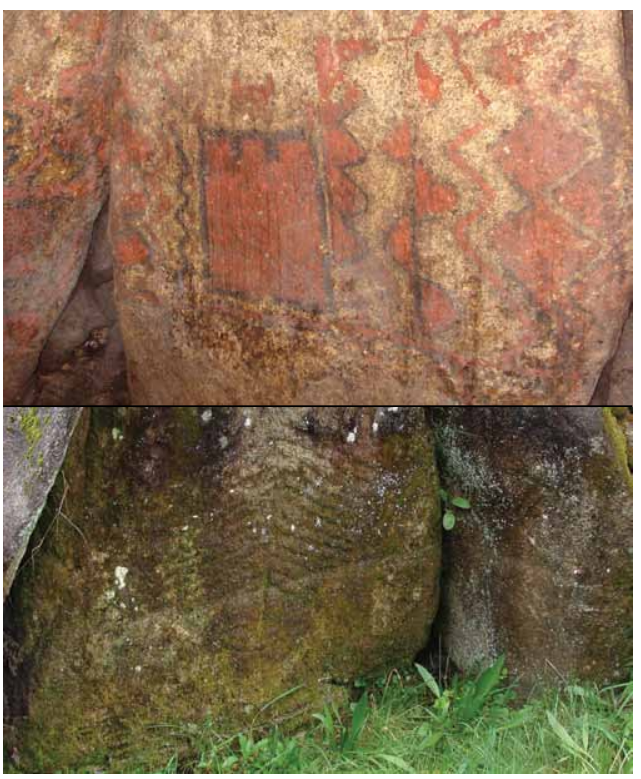

Fig. 3: Painted chamber orthostat of Dolmen de Antelas (top), and carved face of the backstone of Dolmen 2 do Chão Redondo (bottom).

Early Neolithic, to emerge (Senna-Martinez and Ventura 2008a: 318-9). Pottery fragments attributed to this period show characteristics belonging to the traditions of the Early Neolithic from Estremadura, to the southwest, and Andalusia, to the southeast. Based on this, Senna-Martinez and Ventura (2008b: 80) suggest the possibility of a dual origin. However, considering the scarce but increasing evidence for pre-Neolithic occupation of the region, continuity cannot be discounted and the pottery evidence might simply indicate the existence of trade.
Small communities sustained themselves by small game hunting, the gathering of acorn and other winter fruits, and transhumant pastoralism. The raising of ovicaprids - sheep and goat, introduced to the region by the first Neolithic settlers - suggests that spring and summer were spent on high ground pastures and winter on lower ground (Senna-Martinez et al. 1997: 664, Cruz 2001: 313). According to Senna-Martinez and Ventura, later developments can be interpreted as the consolidation and intensification of this seasonal economy.

\section{The Monumentalization of the Landscape}

Radiocarbon dates indicate that the first megaliths were built roughly a thousand years after the first Neolithic communities showed up in the region (Senna-Martinez and Ventura 2008a: 317-50). Senna-Martinez and Ventura (2008a: 333) suggest a division between Middle and Late Neolithic monuments. The first phase $(4,000-3,500$ $\mathrm{BC})$ would be characterized by tumuli with a small polygonal chamber and a short corridor or none at all. Megaliths of the second phase would have been built during the Late Neolithic (3,500-3,000 BC). These are generally bigger and possess developed corridors with heights that are different to those of the chambers, usually composed of 7 or 9 orthostats, and include more complex and differentiated scenic spaces.

Cruz, however, notes that it is difficult to establish a chronology for the small monuments and that, given the vast geographical regions considered, it is possible that megaliths of both sizes were being constructed and used contemporaneously by different communities (2001: 302). The general trend towards more and more complex monuments is nevertheless in-line with arguments put forward for other megalithic groups in Iberia (Cruz 2001: 302). On the other hand, "there is no evidence for the construction of dolmens" after 3,700 BC, even though there is evidence for the continued use of some of them throughout the Late Neolithic. Cruz 
contends that in this period forms of inhumation other than burial in megalithic structures were being practiced but details are still sketchy (2001: 307-8).

Throughout the vast region and time period under consideration the depositional assemblages are quite limited. Microliths, blades, polished stone axes and beads are universally present, whereas ceramic is notable for its absence, even though it shows up in other contexts (Cruz 2001: 305). Arrowheads are also found in the younger and more complex monuments, of about 4,000 $\mathrm{BC}$, once again in-line with the introduction of this artifact in the Iberian northwest.

The Late Neolithic is thus not so much characterized by new architectural styles but by the presence of new depositional artifacts (Senna-Martinez 1994), suggesting an increase in complexity of the funerary rites. New elements include novel pottery styles, projectile points, blade sickles and flint daggers (Senna-Martinez 1994: 18), which are also found in known settlements that have been radiocarbon dated to the same period.

Some tumuli have complex structures in front of them, which have been interpreted as "scenic spaces". The monuments themselves can be seen as temples, with different spaces having different access levels: the chamber and corridor being of limited access and visibility from the outside, and the tumulus itself and surrounding space being a more public space (Cruz 2001: 314). This division might indicate different degrees of participation in rituals: the inside chamber being accessible only by a few who, afterwards, would come out into the atrium which could have been a sort of amphiteatre. Judging by the number of extant cases of megalithic art in the chamber's orthostats, of both the painted and the carved variety (see fig. 3), it stands to reason that they might also have played a role in whatever rituals were enacted there.

Some of the monuments (both of the simple and complex types) had a relatively short lifespan judging by the small quantity and variety of depositions and other artifactual finds, as well as the evidence for "condemnation structures" that permanently closed-off access to the dolmens (Cruz 2001: 290-1). There is evidence for rituals involving fire in these 'condemnation'procedures, as well as a care in the deposition of the stones that closed off the entrance, so that they would blend in with the surrounding cairn.

These monuments can be seen as "true anchors in the landscape for populations that, on the other hand, have a high seasonal mobility" (Senna-Martinez and Ventura 2008b: 82). In this way Senna-Martinez and colleagues fit the monuments into their economic model: the necropolis, by marking the territory, would legitimize its winter occupation. Settlements in the Mondego basin appear in close proximity to the dolmens and suggest an autumn and winter occupation, as evidenced by the presence of central hearths and earth ovens where acorns were roasted.

The archaeoastronomical survey of the orientations of the dolmens conducted by Hoskin lends further credence to this seasonal model (Senna-Martinez et al. 1997). The measured orientations were interpreted as solar alignments to either sunrise or sun-climb (that is, alignments to the sun shortly after sunrise) (Hoskin 2001). For the Mondego dolmens, which exhibit a preference for southeasterly orientations, and thus for autumn/winter sunrises, this seems to fit the hypotheses of the archaeologists. However, the dolmens in the other basins of the region exhibit a preference for slightly northof-east directions, which can only fit an early spring/late summer sun. Outlier orientations that cannot be explained by this generalized solar interpretation abound and this prompted the author to start a more comprehensive survey of the region.

\section{Archaeoastronomical Survey}

\section{Methods}

During the spring of 2010, thirty-one dolmens of the Mondego platform were surveyed for the orientation of their entrances and/or 
corridors. Five more sites were surveyed in 2011, bringing the total to 36 monuments. All measurements were made using a compass, clinometer and a GPS unit, and local magnetic anomalies and magnetic declinations were estimated on-site and, wherever possible, validated afterwards. An in-depth discussion of the employed methodology can be found in Appendix A of Silva (2010). Here only the necessary elements will be reiterated.

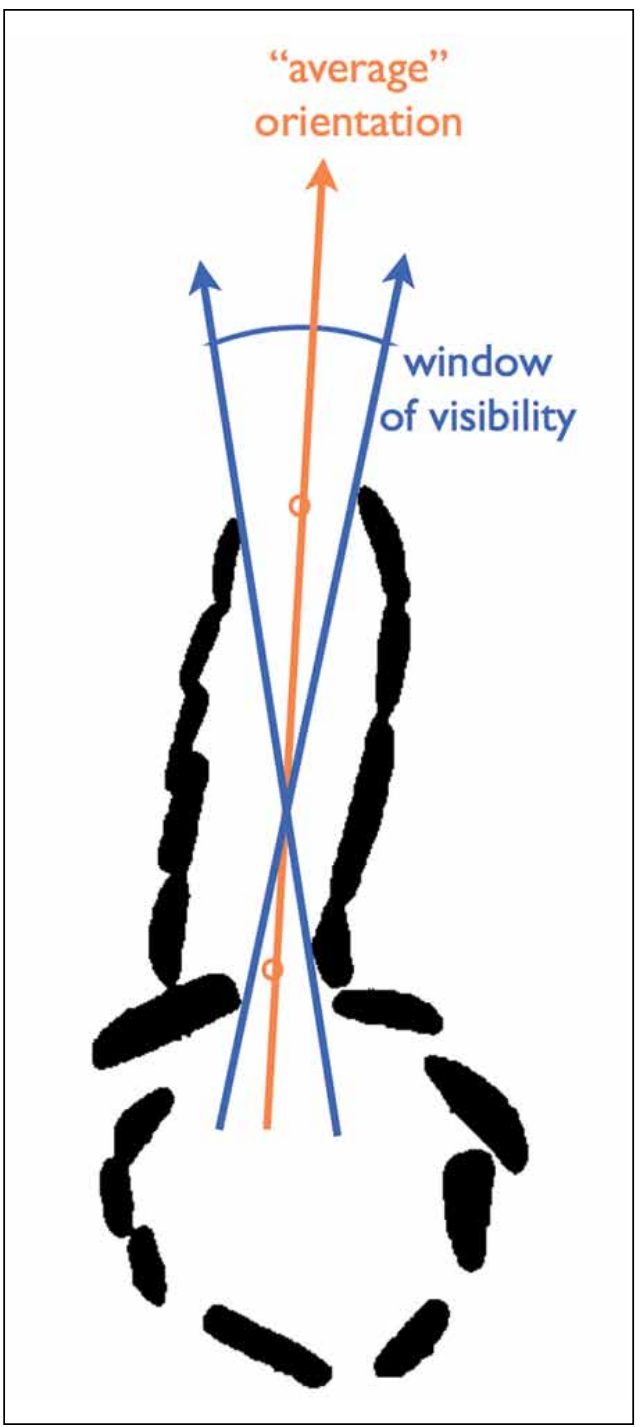

Fig. 4: Orientations measured, in orange and blue, on any given dolmen with a corridor.
The main issue with measuring the orientation of a prehistoric monument, such as an Iberian dolmen, is how to define the line from which one intends to measure the azimuth. The dolmens have been built using rough stones and the geometrical straight-line perfection of later historical peoples didn't seem to much bother these megalithic builders. The chambers are not perfect geometrical figures, and the corridors can bend slightly, close or open up. Finding the orientation to measure is not as straightforward as, for example, measuring the orientation of the base of the Great Pyramid. In the end, choices and assumptions have to be made. Hoskin chose to measure the line defined by the middle point of the backstone (the stone opposite the chamber entrance) and the mid-point of the corridor (2001: 12). This survey purposefully decided to define this line differently in order to test for deviation due to differences in assumptions, as well as to go beyond this approach by measuring a maximum 'window of visibility' (fig. 4).

The 'average orientation' was measured by marking the middle of the chamber entrance and the middle of the corridor entrance, with surveyor's rods carefully leveled (circles in fig. 4). These were then used as backsight and foresight for the compass measurements (orange arrow). For dolmens without corridor the middle of the backstone, and the middle of the chamber entrance were taken.

The 'window of visibility' is defined as the maximum extent of the horizon which, given the dolmen's corridor and entrance geometry, can be seen from the chamber. This amounts to a range of azimuth bearings between a minimum and a maximum value defined by the diagonals of the corridor and chamber entrances (blue arrows in fig. 4). The first orientation, the orange arrow, is thus merely an 'averaged' or 'most likely' orientation, but not necessarily the most meaningful one, as will be shown below.

For archaeoastronomical purposes, the 'horizon altitude' is as important as the azi- 
muth, as the azimuth where an astronomical event occurs changes for different horizon altitudes. For instance, in figure 5, the star rises along the black dotted line, as indicated by the yellow arrow. Because of local topography, the star is seen to rise further south than it would if there was no hill (the point where the black dotted line crosses $0^{\circ}$ of altitude is where the star would have risen in such a situation). Once the orientation one wants to measure has been determined, a clinometer can be used to measure the horizon altitude along that line to the nearest half-degree or less, but only if the horizon is visible.

\section{Data}

With the azimuths and horizon altitudes it is convenient and standard in archaeoastronomy to convert these measurements to a single value, the declination. The declination is the equivalent of latitude on the celestial sphere: it is an angular measure of how far from the celestial equator the point being considered is, measured along a line that is perpendicular to this equator (see fig. 5). Objects lying on the celestial equator will have zero degrees of declination, whereas those at the celestial poles will have ninety (positive for north, negative for south). This simplifies the search for astronomical events along those orientations as well as allowing the comparison of monuments in different geographical regions, as the conversion takes care of the differences in latitude between the sites. ${ }^{2}$

The following table shows the reference number (internal to this survey) and name of the dolmens, as well as the river basin that they are located, true azimuth and horizon altitudes for the "average" orientation as well as the minimum and maximum azimuths for the window of visibility. Some of the horizon altitude values have been corrected by using a Digital Elevation Model (see further below).

\section{Analysis}

The survey finds good agreement with previous measurements by Hoskin (Silva 2010), with the azimuths of the twenty dolmens

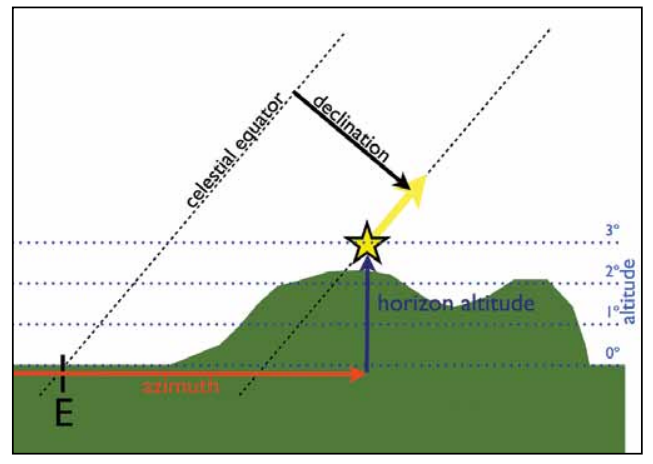

Fig. 5: A star rising behind a hill and all the important measures: the azimuth (red arrow), measured from true north, the horizon altitude (blue arrow), and the declination (black arrow), which is calculated from the other two.

measured by both surveys deviating from each other by $10-12^{\circ}$ or less. This illustrates the case put forward above: different definitions for the line of "average" orientation can yield variations of up to $12^{\circ}$ in azimuth. This, however, corresponds to only a $1-3^{\circ}$ variation in declination and means one can consolidate both surveys by including Hoskin's measurements for those dolmens that weren't included in the present survey (Silva 2010).

Differences in architectural style and depositional assemblages suggest that the regions of central-north and central-south Portugal, defined by the Vouga, Paiva, Torto and Coa rivers and the Mondego river basin respectively, were inhabited by different people (Ventura pers. com.). As noted elsewhere (Silva 2010, in press), this combined dataset continues to validate this regional split. This is better visualized by looking at the orientation histograms for the two regional groups. Fig. 6 shows the declination histograms obtained by making each declination the mean of a stochastic Gaussian curve with standard deviation of $2.5^{\circ}$ and adding them up together. This permits ranges as well as preferences in orientations to be visualized as peaks. Also illustrated as vertical dashed lines, are the declinations of the 


\begin{tabular}{|c|c|c|c|c|c|c|c|}
\hline & Name & Basin & $\mathrm{Az}$ & Alt & Dec & Win Max & Win Min \\
\hline 1 & Orca da Malhada do Cambarinho & Vouga & 111.75 & 4.9 & -12.962 & 122.5 & 102.25 \\
\hline 2 & Dolmen da Lapa de Meruje & Vouga & 88.5 & 7.5 & 6.010 & 92 & 76.75 \\
\hline 3 & Dolmen de Arca & Vouga & 77.75 & 4.7 & 12.349 & & \\
\hline 4 & Orca dos Juncais & Paiva & 76 & 2.5 & 12.206 & 83.75 & 69.25 \\
\hline 5 & Orca de Pendilhe & Paiva & 126 & 2 & -24.909 & & \\
\hline 6 & Orca do Picoto do Vasco & Paiva & 110.25 & 0 & -15.165 & 116.75 & 98.5 \\
\hline 7 & Orca das Castonairas & Paiva & 107.25 & 5.4 & -9.313 & 125.25 & 89.75 \\
\hline 8 & Orca dos Merouços & Paiva & 87 & 1.7 & 3.380 & & \\
\hline 9 & Dolmen 2 do Chão Redondo & Vouga & 66.5 & 0 & 17.606 & 85.5 & 46.75 \\
\hline 10 & Anta de Capela de Mouros & Vouga & 99.5 & 1.2 & -6.400 & 114 & 91.25 \\
\hline 11 & Anta da Cerqueira & Vouga & 70.75 & 2 & 15.801 & 89.25 & 59.5 \\
\hline 12 & Dolmen do Carapito & Mondego & 91 & 3.7 & 1.658 & & \\
\hline 13 & Anta de Cortiçõ & Mondego & 119.25 & 1.6 & -20.626 & 130.5 & 113.25 \\
\hline 14 & Anta da Matança & Mondego & 97.5 & 2.2 & -4.239 & & \\
\hline 15 & Anta da Cunha Baixa & Mondego & 109.25 & 3.2 & -12.342 & 121.25 & 101 \\
\hline 16 & Anta da Orca & Mondego & 109.25 & 6.3 & -10.248 & 147.5 & 75.25 \\
\hline 17 & Anta da Pêra de Moço & Coa & 86.5 & 5.2 & 6.036 & 110.25 & 61 \\
\hline 18 & Lameiro de Cima I & Torto & 87.25 & -0.5 & 1.749 & 96.5 & 79 \\
\hline 19 & Lameiro de Cima II & Torto & 81.25 & -0.5 & 6.269 & 101.75 & 75 \\
\hline 20 & Dolmen do Carvalhal & Torto & 67 & 3.8 & 19.733 & 98.25 & 41.5 \\
\hline 21 & Dolmen/Capela da Sra do Monte & Torto & 87.5 & 3.1 & 3.920 & 105.75 & 69 \\
\hline 22 & Dolmen do Sangrino & Torto & 89.75 & 3.4 & 2.419 & & \\
\hline 23 & Orca das Pramelas & Mondego & 108.5 & 4 & -11.264 & & \\
\hline 24 & Orca de St Tisco & Mondego & 118 & 2 & -19.533 & 141.5 & 93 \\
\hline 25 & Orca do Outeiro do Rato & Mondego & 95.75 & 2 & -3.069 & 124.25 & 74.25 \\
\hline 26 & Orca do Santo & Mondego & 102 & 2 & -7.786 & 112 & 85 \\
\hline 27 & Dolmen da Orca & Mondego & 109.75 & 2.7 & -13.081 & 117.5 & 98.5 \\
\hline 28 & Orca 1 do Ameal & Mondego & * & * & * & & \\
\hline 29 & Orca 2 do Ameal & Mondego & * & * & * & & \\
\hline 30 & Orca da Palheira & Mondego & 94 & 3 & -1.092 & & \\
\hline 31 & Dolmen de Antelas & Vouga & 90.5 & 0.3 & -0.183 & & \\
\hline 32 & Orca de Porto Lamoso & Paiva & 97 & 1.35 & -4.402 & 115.5 & 86 \\
\hline 33 & Anta do Turgal & Torto & 147 & 5.4 & -34.612 & & \\
\hline 34 & Dolmen 1 da Lapinha & Torto & 104 & 5 & -7.160 & & \\
\hline 35 & Dolmen de Areita & Torto & 89 & 3.1 & 2.789 & 113.25 & 73.25 \\
\hline
\end{tabular}

Table 1: Corpus Mensurarum of all surveyed dolmens. The window of visibility (win max and win min) was not possible to obtain for dolmens without a corridor. Those marked with an ${ }^{*}$ have been surveyed, but there are lingering doubts with regards to their entrances, so they have been excluded from this analysis. 
solar extremes (winter and summer solstices, WS and SS respectively), as well as the lunar extremes (southern and northern, minor and major lunar standstills, smLS, nmLS, sMLS and nMLS).

The distribution of orientations of dolmens in the second group is considerably broad, ranging from $-35^{\circ}$ to $33^{\circ}$. Against this seemingly random baseline there is a welldefined, statistically significant peak around declination $4^{\circ}$. This, as previously argued by the author (Silva in press, Silva and Pimenta 2012), corresponds to the expected distribution of the Autumn Full Moon (green dashed line). This is a particular Full Moon, occurring close to the Autumnal Equinox, which is empirically marked by the crossing-over of the sun- and moonrise positions (Silva and Pimenta 2012).

The situation is, however, not as clear-cut for the Mondego dolmens: although there seems to be a preference for negative declinations, there isn't a unique well-defined peak. This could be due to the presence of several peaks close to each other, one of which could be a Spring Full Moon (about $-4^{\circ}$ ) and another one of the lunar extremes, the southern minor standstill or the winter solstice sunrise (Silva, in press), with a possible third around $-10^{\circ}$ of declination. In order to shed some further light on the orientation of these dolmens the second half of this paper focuses on a single nucleus of Neolithic activity in the Mondego valley.

\section{The Carregal do Sal Megalithic Nucleus}

The nucleus of Carregal do Sal (the blue markers in Fig.1) is located on the northern bank of the Mondego valley, a mere kilometre and a half from the riverbed. It is composed of eight of the measured dolmens (refs 23-30), as well as several as of yet unsurveyed smaller ones and other tumuli.

The distribution of the orientation of these dolmens, similarly to the whole of the Mondego valley, exhibits a range of negative declinations, with a slight preference for negative $10-12^{\circ}$, a value for which there is no clearly defined lunar or solar event. ${ }^{3}$ This peak is also visible in fig. 6, even though it is not as prominent as it is for this nucleus.

\section{The horizon at Carregal do Sal}

Throughout the survey the horizon of some dolmens, in Carregal do Sal and elsewhere, could not be surveyed because of tall vegetation, mostly pine trees, which covered the view. In Silva (2010) empirical guesstimates were indicated and used for the calculation

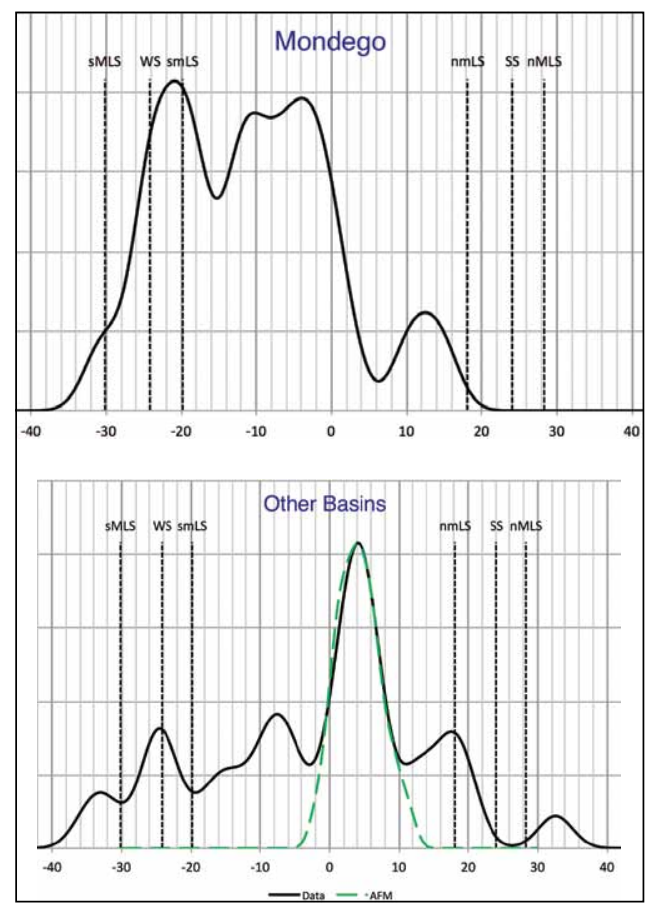

Fig. 6: Declination histograms for the consolidated dataset. Dolmens of the Mondego basin are shown above, and of other basins below.

of declination but using digital elevation data one can recreate vegetation-free horizons for all sites and confirm or correct them.

A Digital Elevation Model (DEM for short) is a computer model composed of a raster of cells where each has the value of the mean elevation across the area defined by that cell (Connoly and Lake 2006: 27). There are several DEM models around, using elevation data 


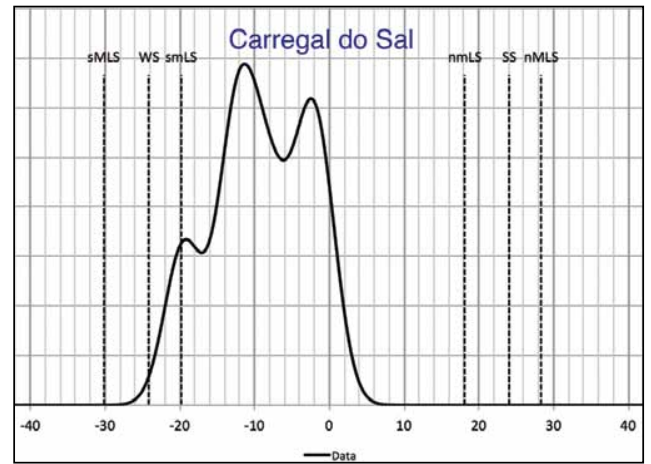

Fig. 7: Declination histogram for dolmens in Carregal do Sal.

acquired and treated differently. One such case is the SRTM or Shuttle Radar Topography Mission, which comprises elevations determined roughly every 100 feet north-south and east-west for the US and every 300 feet elsewhere, obtained via radar interferometry by the Space Shuttle program during February 2000 (US Geological Survey 2010).

With this data one can use a GIS software package to create a virtual reconstruction of the horizon profile at any location and/ or calculate the horizon altitude on a given direction. HeyWhatsThat is a free, online, utility that uses SRTM data to do just that (HeyWhatsThat Team 2012), requiring only the latitude and longitude of the archaeological site. It is also fully integrated with Google Maps, so one can export one's horizon profiles and viewsheds.

Using HeyWhatsThat, most of the horizon altitudes that were possible to measure in the field have been validated to within a degree. Guesstimates have now been replaced by the virtually generated horizon altitudes (see table 1 above), and have been used to calculate the declination histograms shown in Figs 6 and 7.

By looking at the horizon profiles of the eight surveyed dolmens of Carregal do Sal it quickly became clear that only Orca da Palheira (ref.30) didn't have a distant horizon the view was obstructed by local topography. Out of the remaining seven, Ameal 1 and
Ameal 2 (refs 28 and 29) are small dolmens without corridors, and there are still open questions regarding the orientation of their entrances (if they ever had them: Silva 2010, Ventura pers. com.), whereas the window of visibility of Orca das Pramelas (ref.23) could not be surveyed at the time. This leaves only four dolmens: Orca de Santo Tisco, Orca do Outeiro do Rato, Orca do Santo and Dolmen da Orca (refs 24-27). The entrances of all of these are oriented towards a particular mountain range in the SE direction: Serra da Estrela (Star Mountain Range), which contains the highest peak in continental Portugal. The figure below shows one such example, that of Orca de Santo Tisco (see also fig. 9 below for all four dolmens).

Figure 8 shows a $360^{\circ}$ panorama of the horizon around the dolmen, as recreated by HeyWhatsThat. The different colours represent different distances of the topographical features (green is closest, then blue, dark magenta and finally purple), whereas the inverted red triangles mark known peaks. The cardinal directions are also marked. The vertical scale has been exaggerated 8.3 times to facilitate the identification of topographic features and vertical lines mark the "average" orientation (in brown) as well as the measured window of visibility (in black). To facilitate visualization, the areas of the horizon that can't be seen from within the dolmen's chamber have been greyed out.

The brown line marks the centre point of the corridor window (not always, see the appendix to Silva (2010) for a discussion), but the window permits a much wider range of the horizon to be seen from within the chamber. This information is not accurately encoded by a histogram of the "averaged" orientations, such as those of figures 6 and 7 .

The importance of topographic features for Mesolithic and Neolithic people has been highlighted by Tilley (1994). He argued that, in the Mesolithic 'known, named and significant places [were] linked by paths of movement to which populations repeatedly returned during their seasonal activity rounds' (1994: 


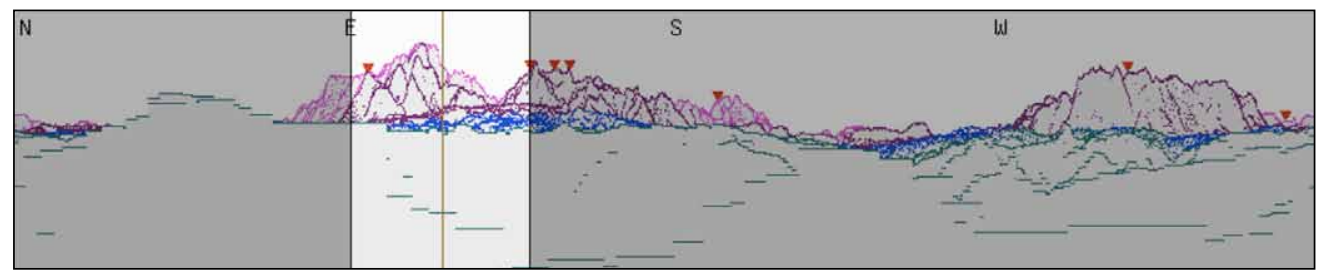

Fig. 8: Horizon profile of Orca de Santo Tisco showing the measured "average" orientation (brown line), as well as the maximum window of visibility (non-shaded area).

202). In the Neolithic this dynamic would have changed, as the megaliths became the anchors of the seasonal movements. Important landscape points 'became captured in the orientation of morphological features of the monuments and their placement in the landscape' (1994: 202-3).

Besides having potentially ritual and funerary functions, the dolmens of the Mondego valley also marked the winter territories of their builders (Cruz 2001: 311, Senna-Martinez and Ventura 2008b: 82), whereas Star Mountain Range, in the horizon, marked their summer pastures (SennaMartinez and Ventura 2008a: 332). It seems that both man-made and natural landscape markers were anchoring the seasonal movement. The orientation of the Carregal do Sal dolmens towards Star Mountain Range, then, makes sense from a landscape/spatial perspective.

This, however, does not preclude the possibility of an astronomical event marking the seasonal movement temporally. Considering the lack of well-defined solar or lunar explanations for the peak of the distribution one can explore whether, at the time of the megalith builders, any bright stars would rise in that range.

\section{Aldebaran rising}

The only bright stars that, around 4,000 BC, rose in the neighbourhood of the mysterious $-11^{\circ}$ peak are Betelgeuse and Aldebaran, in the modern constellations of Orion, the Hunter, and Taurus, the Bull, respectively. Both stars are the brightest in their respective constellations (apparent magnitudes of
0.45 and 0.87 respectively $)^{4}$ and both are coloured red even to the naked eye.

Axial precession, also known as precession of the equinoxes, is a wobble of the Earth's axis against the celestial sphere, over very long periods of time. For an Earth-bound observer it would look like the background of stars, as a whole, is moving very slowly. But the stars themselves also have an intrinsic movement, called proper motion, which is different for different stars. These two factors conspire to move the stars around over periods of thousands of years so that today they do not rise and set where they rose and set six thousand years ago. Table 2 below shows the declination of the two stars under consideration at three points of the megalithic phase ${ }^{5}$.

Figure 9 shows a section of the horizons for the four identified dolmens of the Carregal do Sal nucleus, along with the window of visibility (unshaded areas) and "average" orientation (vertical brown line). The location of the rise of Aldebaran (in red) and Betelgeuse (in blue) is also indicated by the coloured shaded areas, the right-hand side limit marking the rise position in $4,300 \mathrm{BC}$, and the lefthand side in 3,500 BC.

Both Betelgeuse and Aldebaran, in the period 4,300-3,500 BC would thus be seen to rise from within the chambers of the four dolmens, even though only a glimpse of Betelgeuse would be possible from Orca do Santo, as the star would have risen very close to the right-hand side of the window. ${ }^{6}$

Even though these stars, whenever visible, would always be seen to rise in the same place on the horizon throughout the year, stars that lie so close to the celestial equator go through a period in which they are not 


\begin{tabular}{|l|c|c|c|}
\hline & Year BC & Declination & Heliacal Rising around \\
\hline Betelgeuse & 4,300 & $-14^{\circ} 38^{\prime}$ & 21 May \\
\hline & 4,000 & $-12^{\circ} 58^{\prime}$ & 23 May \\
\hline & 3,500 & $-10^{\circ} 13^{\prime}$ & $29 \mathrm{May}$ \\
\hline Aldebaran & 4,300 & $-12^{\circ} 18^{\prime}$ & $18 \mathrm{Apr}$ \\
\hline & 4,000 & $-10^{\circ} 39^{\prime}$ & $21 \mathrm{Apr}$ \\
\hline & 3,500 & $-7^{\circ} 51^{\prime}$ & $27 \mathrm{Apr}$ \\
\hline
\end{tabular}

Table 2: Declination and approximate date for the heliacal rising of Aldebaran and Betelgeuse during the megalithic phase.

visible in the night-sky. Considering SennaMartinez and Ventura's seasonal model, it would be interesting to look at the seasonality of their 'heliacal rising', their first appearance after this period of invisibility.

In the epoch under consideration, the heliacal rising of Betelgeuse would have occurred between 21-29 ${ }^{\text {th }}$ May, or thereabouts, whereas Aldebaran heliacally rose around $18-27^{\text {th }}$ April (see table 2$)^{7}$. The precision of these dates needs to be taken with a pinch of salt, as visibility, climatic and other observational criteria might not permit the star to be seen so close to the horizon on a given day. Generally, however, one can say that Aldebaran reappeared in the eastern sky in late April/early May, whereas Betelgeuse did so in late May/early June.

The seasonal model states that, in the spring and summer, the dolmen builders would take their ovicaprids to the high pastures of Star Mountain Range to take advantage of its grazing grounds. If the dolmen-builders were observing the heliacal rise of these stars, as is here proposed, they could have used it as a temporal marker for their transhumant movement to high pastures. The period of invisibility of the stars would provide the perfect amount of time to make preparations for whatever rituals were going to be enacted in the dolmens, as well as for the move to higher grounds. Although both identified stars can fit this picture, it can be argued that Aldebaran, with its earlier heliacal rising, just a month after the Vernal Equinox, fits this picture better than Betelgeuse.

\section{The origin of the name of Star Mountain}

One can now consider whether other sources support the possibility that the mountain range's name is linked to this very star, and whether the name may thus be as remote as the Neolithic itself (if not older). Local ethnography and folklore are filled with myths and stories that explain the origin of the name of Star Mountain Range. There are several recorded stories by locals on this topic, some of which have been recorded by professional folklorists (CEAO 2006). The simplest version is the one currently on the website of the Covilhã City Council (C M Covilha 2012), one of the five municipalities that surround the mountain range. It goes something like this (author's translation):

People say that the name Star Mountain Range was given in the olden days by a shepherd living in an unknown place in the Mondego valley. He spent his nights contemplating a star that was so bright that it illuminated the top of a nearby mountain range. One day he decided to take his faithful dog and follow the scintillating light that attracted him so much. After climbing for many days they reached the peak. Impressed by the luminosity of the star the shepherd told his dog: "to this place that seems to be favoured by the celestial objects [astros] I will name Serra da Estrela [Star Mountain Range], and you that accompanied me I shall give the same name. 


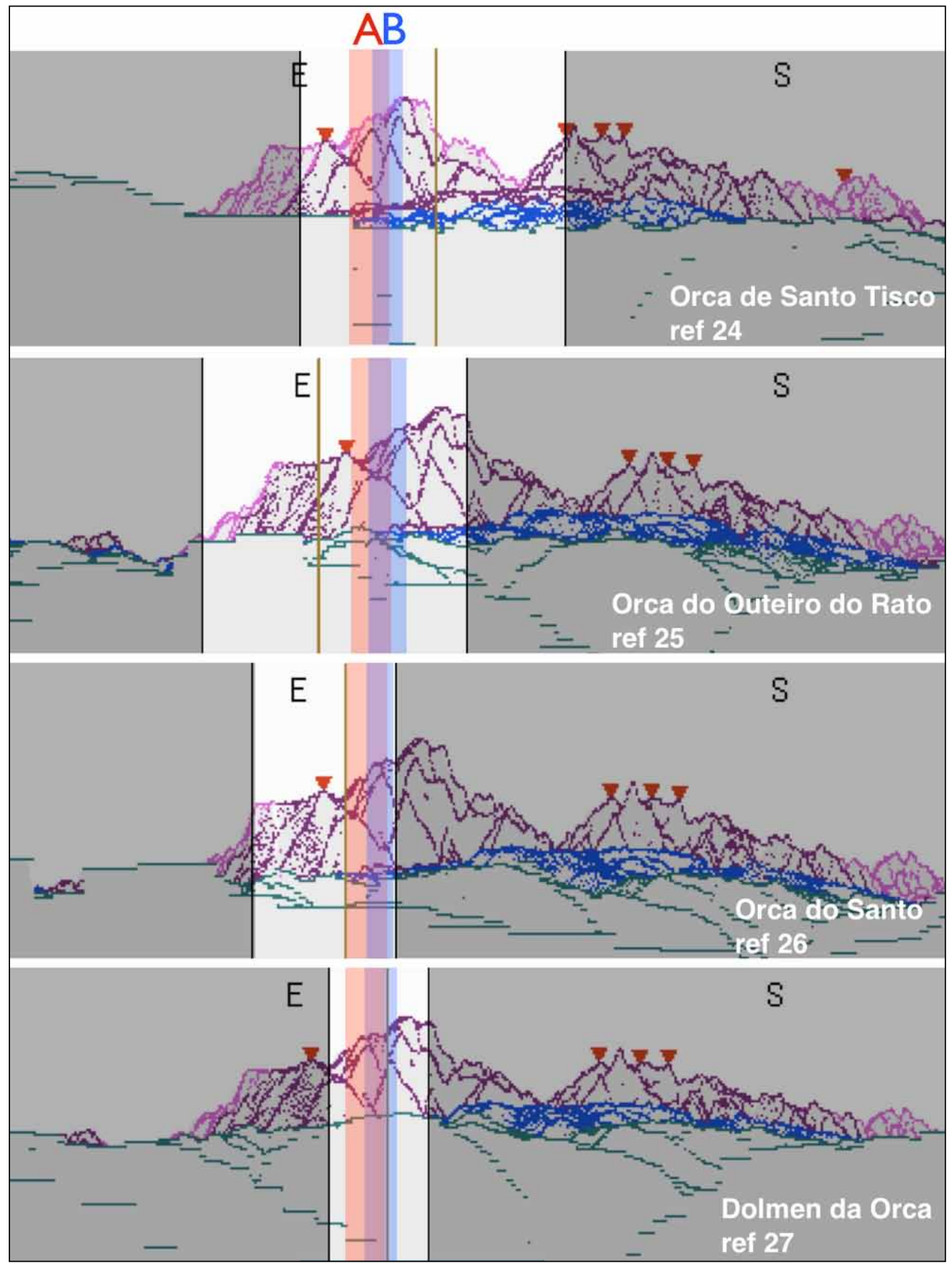

Fig. 9: Sections of the horizon profiles of all four dolmens in Carregal do Sal with a distant horizon in order of reference number. The horizon outside the windows of visibility is greyed out. Also marked is the variation in rise position of Aldebaran (red) and Betelgeuse (blue) during the megalithic phase. 
The latter part refers to the Serra da Estrela dog, also known as the Portuguese Shepherd and one of the oldest breeds in Portugal. There are several other versions of this story, some of which include other elements and mythemes $^{8}$ but the central plotline remains the same. All versions remark how unique this star is, either by mentioning that the star illuminated the top of the mountain, just as in the version above, or by, at the end of the story, describing it as still today shining "more", or "differently", than the other stars.

The collection and analysis of Portuguese folktales was neglected for a long time but this has been increasingly addressed in the past decades. Notable projects include the online "Archive of Portuguese Legends" (CEAO 2006) by the Centro de Estudos Ataíde Oliveira (University of Algarve), which collects at least three different versions of this tale. The interpretation of myth and folklore has a long tradition in academia, and several schools of thought have pursued different interpretative paths. ${ }^{9}$

The tale above, however, fits nicely with the hypothesis put forth in this paper. The main hero of the tale is a shepherd living in the Mondego valley, from where he would see a particular star atop a mountain range. This triggered him to "follow" this star, taking his dog, a shepherd dog, with him. The comparison with the Neolithic people of the Mondego basin is very suggestive. Firstly they also inhabited the river valley - the megalithic nucleus of Carregal do Sal. Secondly, the evidence suggests that they too, like the hero of the tale, were transhumant pastoralists. And thirdly, archaeologists believe that these people would take their ovicaprids to graze on the high fields of Star Mountain. In the toponymical tale the transhumantic movement of the shepherd is triggered by the appearance of this star over the mountain range. In the case of the megalithic builders Betelgeuse or, perhaps more likely, Aldebaran could have served the same purpose, and the dolmens would then have served as spatial and temporal markers for this important event.

\section{Conclusions}

Although not as monumental as Stonehenge, Avebury or Newgrange, the Iberian dolmens still demonstrate some level of cultural unity across vast areas, as well as regional diversity in both architectural elements and in the orientation of their chambers and corridors. This survey has focused on an area of roughly $10,800 \mathrm{~km}^{2}$ and, together with previous surveys, included fifty-eight dolmens. Within this area, at least two regional groups can be distinguished and this is supported by landscape phenomenology and archaeoastronomical arguments.

Judging by the analysis of the necropolis of Carregal do Sal, the dolmens of the Mondego valley show a preference for locations from which Star Mountain Range, containing the highest peak in continental Portugal and the very source of the Mondego river, can be seen. Outside of Carregal do Sal there is at least one other dolmen whose horizon profile analysis yields similar conclusions (Anta da Orca, ref.16).

From within the chambers of all these dolmens it would not only be possible to see Star Mountain Range in the horizon, it would also be possible to see the stars Betelgeuse and Aldebaran rising above it. These two stars are not only very bright they are also both red. Around 4,000 BC, when the megaliths were built, these stars would disappear from the night-sky at the end of February/beginning of March, not to be seen for two lunar cycles (two and a half in the case of Betelgeuse), until they would reappear in the eastern sky at dawn before sunrise, just as spring was starting to reinvigorate the landscape. This was when the Neolithic communities of the Mondego valley would "follow this star" and transition to the high pastures of the mountain range it illuminates. One can't be sure whether it was Betelgeuse or Aldebaran that was being targeted, or even both, but the timing of the heliacal rising of the latter, closer to the Vernal Equinox, would make it better suited to be used as a seasonal marker. The presence of the Hyades star cluster around 
Aldebaran, giving it a "different shine", would further support this, based on a (semi-)literal reading of the toponymical folktales about Star Mountain Range.

Unfortunately this effect is no longer observable today as, due to axial precession and proper motion, Aldebaran and Betelgeuse have both migrated further north, to positive declinations $\left(+16.5^{\circ}\right.$ and $+7.5^{\circ}$ respectively). They now rise north of east and not in alignment with Star Mountain Range as seen from Carregal do Sal.

The use of the heliacal rising of a star as a marker for ritual, a new season and the new year is not without historical and ethnographic precedent. For instance, the ancient Egyptians timed their ritual calendar by the heliacal rise of Sirius (Schaefer 2000, Steele 2007) and, in the ethnographic present, South American Indians mark the heliacal rise of the Pleiades (Lévi-Strauss 1986). As is the case with the dolmen builders of the Mondego valley, the heliacal rises of the chosen stars coincide with important events in the subsistence economies of these peoples: in Egypt it coincided with the flooding of the Nile, rebooting the agricultural cycle; in South America it coincides with the shift from wet to dry season.

Three important epistemological points have also been highlighted in this work. Firstly, that landscape archaeology and archaeoastronomy are not incompatible, but complementary: topographical features could have been used as markers for astronomical events. Secondly, that the emphasis on methodological precision, which has characterized megalithic archaeoastronomy, should be alleviated in favour of horizon surveys with a special eye for topography and phenomenology. Megalithic monuments, such as the studied dolmens, are imprecise by their very nature. Measuring an "averaged" straight line to as much precision as one can (for instance by using a theodolite) does not counter the fact that one cannot be sure whether one is measuring the 'right' line (or whether such a line even exists). The build- ers might have intended the orientation of the chambers to simply point out, indicate or direct one's gaze towards a broad area of the horizon, and an 'obvious' topographical feature, within that horizon range, would mark an important astronomical event. Measuring several of these 'averaged' lines and plotting a histogram of these orientations is not enough: one needs to shed modern, mathematical and geometrical assumptions and immerse oneself in the landscape itself, as Tilley proposed (1994).

Both points have already been made by Clive Ruggles (1999: 156-63), based on his experience surveying prehistoric stone circles, rows and mounds in the British Isles. This certainly seems to be the case for the Carregal do Sal nucleus as well, and thus might very well be extendable to the breadth of Megalithic Europe.

A third point relates to the interpretation and encoding of information in folktales and myths. While the stellar hypothesis argued here is completely independent of the interpretation of the legends that explain the origin of the name of the mountain range, this possibility certainly adds strength to the argument. Tilley said that the "building of the monuments prevented the ritual and mythological significance of particular places being lost and forgotten" (1994: 204). If the reading of the toponymical myth made here is valid, it means that the reverse can also be true: the folktale preserved the link between star and mountain range that was only visible from across the Mondego valley where the Carregal do Sal dolmens lie. Together, the mountain range and the dolmens anchored a seasonal movement that is, in a reduced form, still practiced by local shepherds today.

\section{Acknowledgments}

The author would like to thank Roslyn Frank, Fernando Pimenta and the anonymous referee for careful reading of the manuscript, as well as insightful discussions on the topic. 


\section{Notes}

1 Dates throughout the paper are in cal BC.

2 The same astronomical events, say sunrise on the winter solstice, occur at different azimuths depending on latitude and horizon altitude, but always at the same declination. Monuments at different latitudes and landscapes can then be oriented towards different azimuth bearings, but still be aligned to the same astronomical events. Declination allows one to test this.

3 One possible interpretation for this peak could be sunrise on specific days of the year, namely around the $20^{\text {th }}$ February and the $22^{\text {nd }}$ October. These dates, particularly the February one, seem to be too early to mark the spring transition.

4 The apparent magnitude is a measure of the brightness of a celestial object as seen by an observer on Earth. The brighter the object appears, the lower the value of its magnitude.

5 Because different software packages use different algorithms to calculate the positions of stars in the past the values given in table 2 are the mean of the values of declination, to nearest arc-minute, between three software packages: Starry Night Pro Plus, Stellarium and Cartes du Ciel, the last two of which are freely available online.

6 The window of visibility of Orca do Outeiro do Rato seemed to exclude the possibility of observing the rise of any of these stars as they'd have risen south of the southernmost limit of the window. However, the corridor of this particular dolmen bends $10^{\circ}$ towards the south halfway through (Silva, 2010), creating a new window of visibility that looks directly at the highest topographical feature on the horizon and to the rise of Aldebaran and Betelgeuse.

7 These were calculated by the author using an algorithm developed in Matlab, based on the works of Schaefer (1987, 1997, 2000) and Purrington (1988). The dates are given in the modern calendar, i.e. April $21^{\text {st }}$ corresponds to the thirty-first day after the Vernal Equinox( which occurs on March 21 ${ }^{\text {st }}$ ).
8 Examples include the personification of the star, the death of the dog from exhaustion, before they reach the peak and the existence of a king that seeks to buy the stellar woman from the shepherd, to no avail.

9 Examples include, but are not limited to, the Junguian, Proppian and Lévi-Straussian schools (e.g. Segal 1998, Propp 1968, Lévi-Strauss 1986).

\section{References}

Connoly, J and Lake, M 2006 Geogra phical Information Systems in Archaeology. Cambridge: Cambridge University Press.

CEAO 2006 Archive of Portuguese Legends [online], http://www.lendarium.org

Covilha, C M 2012 Parque Natural [online], http://www.cm-covilha.pt/simples/?f=2612 [accessed 2th August 2012]

Cruz, D J 2001 O Alto Paiva: megaltismo, diversidade tumular e práticas rituais durante a Pré-história Recente. PhD Dissertation. Coimbra: Universidade de Coimbra.

HeyWhatsThat Team 2012 HeyWhatsThat Testbed [online], http://www.heywhatsthat.com/main-0904.html

Hoskin, M et al. 1998 Studies in Iberian Archaeoastronomy: (5) Orientations of Megalithic Tombs of Northern and Western Iberia. Journal for the History of Astronomy, 29, S39-88.

Hoskin, M 2001 Tombs, Temples and their Orientations, Bognor Regis: Ocarina Books.

Lévi-Strauss, C 1986 The Raw and The Cooked - Introduction to a Science of Mythology 1. Middlesex: Penguin Books [1964].

Propp, V 1968 The Morphology of the Folktale ( $\left.2^{\text {nd }} \mathrm{ed}\right)$. Austin: University of Texas Press.

Purrington, R D 1988 Heliacal Rising and Setting: Quantitiative Aspects. Journal for the History of Astronomy, 19, S72-84.

Rodrigues, S M 2000 A estação neolítica do Prazo (Freixo de Numião - Norte de Portugal) no context do Neolítico Antigo do Noroeste Peninsular. Algumas considerações preliminaries. In: Actas do 30 Congresso de Arqueologia Peninsular (vol.3). Porto: ADECAP, 149-180. 
Ruggles, C 1999 Astronomy in Prehistoric Britain and Ireland. New Haven and London: Yale University Press.

Schaefer, B E 1987 Heliacal Rise Phenomena. Journal for the History of Astronomy, 18, S19-33.

Schaefer, B E 1997 Heliacal Rising: Definitions, Calculations, and Some Specific Cases. The Archaeoastronomy and Ethnoastronomy News, 25.

Schaefer, B E 2000 The Heliacal Rise of Sirius and Ancient Egyptian Chronology. Journal for the History of Astronomy, 31, 149-55.

Segal, R A 1998 Jung on Mythology. London: Routledge.

Senna-Martinez, J C 1994 Megalitismo, habitat e sociedades: a bacia do médio e do alto Mondego no conjunto da Beira Alta (c. 5200-3000BP). Estudos Pré-históricos, 2, Viseu, 15-29.

Senna-Martinez, J C, López-Plaza, M S and Hoskin, M 1997 Territorio, ideología y cultura material en el megalitismo de la plataforma del Mondego (Centro de Portugal). In: O Neolítico Atlántico e as Orixes do Megalitismo. Actas del Coloquio Internacional (Santiago de Compostela, 1-6 de Abril de 1996). Santiago de Compostela: Universidade de Santiago de Compostela, 657-76.

Senna-Martinez, J C and Ventura, J M Q 2008a Do Mundo das Sombras ao Mundo dos Vivos: Octávio da Veiga Ferreira e o Megalitismo da Beira Alta, Meio Século Depois. In: Homenagem a Octávio da Veiga Ferreira Estudos Arqueológicos de Oeiras, 16, 317-50.
Senna-Martinez, J C and Ventura, J M Q 2008b Neolitização e Megalitismo na Plataforma do Mondego: Algumas Reflexões sobre a Transição Neolítico Antigo/Neolítico Médio. In: Actas do IV Congreso del Neolítico en la Península Ibérica, Alicante, 77-84.

Silva, F A P 2000 A estação EpipaleolíticaMesolítica do Cabeço Branco (Portinho, Oiã, Oliveira do Bairro, Aveiro). Arqueologia, 25, Porto, 79-88.

Silva, F 2010 Cosmology and the Neolithic: A New Survey of Neolithic Dolmens in Central Portugal. Journal of Cosmology, 9 , 3094-3106.

Silva, F(in press) Equinoctial Full Moon Models and Non-Gaussianity: Portuguese Dolmens as a Test Case. In: Rappenglueck, M, Rappenglueck B and Campion, N (eds.) Astronomy and Power. Oxford: Archaeopress.

Silva, F and Pimenta, F 2012 The Crossover of the Sun and the Moon. Journal for the History of Astronomy, 43(2), 191-208.

Steele, J M 2007 Calendars and Years: Astronomy and Time in the Ancient Near East. Oxford: Osbow Books.

Tilley, C 1994 A Phenomenology of Landscape. Oxford: Berg Publishers.

US Geological Survey 2010 Shuttle Radar Topography Mission [online], http://srtm.usgs.gov

Ventura, J M Q 1998 A Necrópole Megalítica do Ameal, no Contexto do Megalitismo da Plataforma do Mondego. MA dissertation. Lisboa: Faculdade de Letras da Universidade de Lisboa. 